\title{
Structural Limitations On Finance Of Technology Companies In The European Union
}

Roberta Adami, (E-mail: R.Adami@ westminster.ac.uk), University of Westminster, United Kingdom James Waters, (E-mail: J.M.Waters@ westminster.ac.uk), University of Westminster, United Kingdom

\begin{abstract}
The paper examines the connections between financial structures and the growth of the technology sector in the European Union, identifying the main financial factors affecting the sector. It proceeds to a regression analysis using a new dataset. The variables are selected to give insight into both the promotion of innovation and its financial realisation. The paper summarises the conclusions in a form suitable for use by European Union policymakers.
\end{abstract}

\section{INTRODUCTION}

$\mathrm{t}$ was the emergence in the 1990s of the "new" economy in the United States, and the world-beating
economic performance which followed from it, which focussed the attention of policymakers and
academics on the American way of promoting technology companies. Market-driven and profitmotivated, its approach was very different from the predominant continental European approach where often banks act as financiers and value good relationships with companies, pursuing long-term growth, rather than a "quick buck". The pervasive links of technology in the wider economy, and the importance of leading economic revolutions, meant European countries had to follow the success of the United States, soon, or risk falling behind still further.

Any fast growing industry would benefit from adequate finance to meet its expansion plans, which are likely to be risky and speculative. A bank-based financial system may be dominated by large, slow, conservative incumbents who lack the agility of, say, venture capitalists, and so are unsuitable sources of finance for the new economy. Venture capitalists may bring valuable expertise and specialisation to business start-ups, another feature that may be beyond the capacity of a bank-led financial market. Furthermore, a large equity market might give entrepreneurs the chance to raise further capital at a later stage of their corporate life.

On the other hand, such a presentation caricatures any real market. Continental Europe has seen several equity markets for new technology companies established, although without the success of the NASDAQ market in New York. Governments take an active role in the development of industries; frequently, they take the centre stage. Those in developed countries usually protect their infant industries, and often provide finance directly to new companies or support finance providers. The German Government has actively encouraged business start-ups, as did the United States administration. Other factors which could limit growth of the technology sector relate to the extent of funding of research by business, and the ease of creation and liquidation of businesses.

This paper uses regressions to compare the effects of the various financial and structural influences on the technology sector, using cross-country data. Unlike many studies, it differentiates and analyses both factors influencing innovation and those influencing its conversion to economic growth. The regressions consider the key financial factors identified by qualitative assessment, as well as the initial development of the country. concludes.

Section 2 assesses their sources of funding in Europe. Data analysis is undertaken in Section 3, and Section 4 


\section{FINANCE SOURCES FOR TECHNOLOGY COMPANIES}

For the past decade we have witnessed some of the most significant and rapid advancements in ICT, that, from a financial point of view, have led to new possibilities of investment and high rates of return. Sustainable economic growth can only be attained through investment opportunities with positive marginal rates of return (Bugamelli et al. 2003), therefore it is of paramount importance that investors in high-tech firms be rewarded according to the high risk they are prepared to take on.

It has been argued that a successful and steadfast development of the high-tech sector could be highly reliant on accessible and efficient equity markets. According to Carpenter and Petersen (2002) the fact that the United States has a highly developed equity market, extensive venture capital, particularly focused on early-stage investment of high-tech firms, and a thriving high-tech sector is not a coincidence. However, although the private equity industry has a crucial role in financing and creating successful enterprises in Europe as well as in the United States (Green 2003, BVCA report 2002), it can still be argued that bank debt does not critically hinder a healthy expansion of the high-tech sector. Germany can be cited as an example of one of the economies where the high-tech industry and venture capital are booming most in Europe despite having a bank-based financial system.

\section{Bank Debt Versus Equity Financing}

The argument in favour of banks with regard to their ability to fund the high-tech sectors resides in their capacity to combine and share the costs of selecting and monitoring different investment projects. Banks can also outperform capital markets with issues pertaining the sharing of short-term risk of the investments and of being able to promptly subsidise entrepreneurs facing temporary liquidity problems (Bugamelli et al. 2003).

Although there is still uncertainty on whether a well developed financial system is the foundation for economic growth or whether it is rather the other way around as Robinson (1952) argues, according to Beck and Levine (2001), what matters for a sustainable economic growth is not the choice between a bank-based or marketbased financial system, but rather the level of development of the financial sector as a whole. What is essential for the equilibrium rate of the real economic growth is that any difference in financial systems be accounted for by differences in the legal systems.

However even though the equilibrium rate of the economy's growth might not be dependent on the structure of financial markets, a country's productive specialisation can be, and more often than not is, affected by it (Bugamelli, et al. 2003). It can be observed that generally where equity markets are less developed, firms typically more dependent on them are smaller in size and fewer in number.

Banks typically require tangible assets as collateral to their investments, while the input and output of firms where R\&D is paramount for success such as ICT enterprises generally take on the form of intangible assets (i.e. skilled human capital, know-how, etc.). The problem of asymmetric information, as studied by Nobel Laureates Akerlof, Spence and Stiglitz (2001), seems particularly relevant when we consider investment in the high-tech industry, often backed by intangible assets, so increasing the complexity of evaluating the risks and returns. Information asymmetries can give rise to a problem faced by fund providers called adverse selection, whereby investors may be likely to finance a disproportionately high number of undesirable projects. Because of the risks involved institutional finance providers, typically banks, may decide to charge hefty premiums or restrict the supply of funds to firms in the early stages of their development. The above may explain why in a milieu dominated by large informational asymmetries, high-tech firms can find themselves at a disadvantage when attempting to obtain any significant quantities of debt finance.

The availability of different ways of financing the "new economy" is widely deemed to be a focal point when considering the role played by ICT firms in a country's economic growth. It has been argued that these firms would require new methods of financing such as external equity financing, typically angel financing ${ }^{1}$, and venture capital,

\footnotetext{
${ }^{1}$ The so called Business Angels are private investors who invest in unquoted young entrepreneurial firms. They usually are former entrepreneurs or executives.
} 
particularly in the early stages of their evolution. Even where the equity markets are well developed (like in the US), there still exists what has been described as "equity gap". The equity gap is identified as the lack of small risk capital (namely below $\$ 500,000$ for an US firm) from institutional sources for those companies that are still at their seed, start-up or early-growth stages. Specifically the fixed costs of investment evaluation and screening make small investments unprofitable for venture capitalists and not viable for banks, generally reluctant to make unsecured lending. One of the reasons for such unwillingness to invest small amounts of capital, regardless of the actual availability of funds, can be identified in the general market inefficiency and fragmentation ${ }^{2}$, as the information on start-ups is typically too scarce.

Venture capital has been identified as one of the chief catalysts to the rapid expansion of new technologies in which new firms play a crucial role (Dubocage and Rivaud-Danset, 2002). However it is recognised that venture capital cannot finance innovation on its own. Specifically for the US market, the sources of funds have been categorized as follows:

\section{Funding Stage}
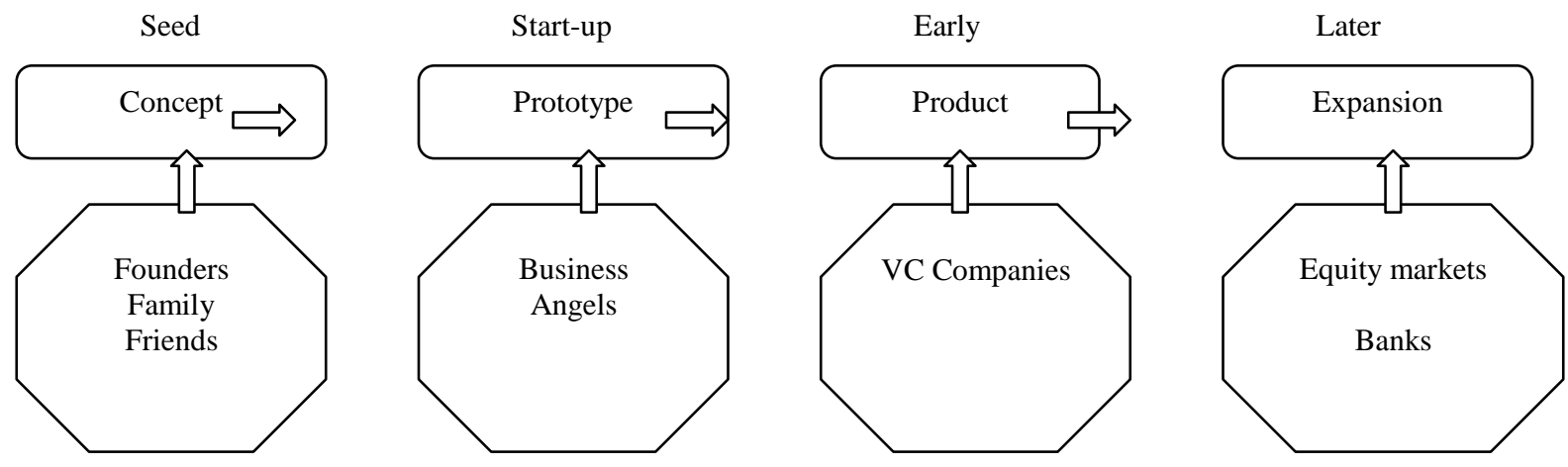

Adapted from: "Venture financing chain" http://www.1000ventures.com/presentations/venture_financing_chain.html

The above Venture financing chain illustrates the typical funding patterns in the US market, while in Europe business angels are often replaced by public authorities. The so called "Business Angels", crucial at the start-up stage of entrepreneurial evolution, are private investors, usually entrepreneurs or managers, funding unquoted young companies, also providing experience and managerial skills. According to the Global Entrepreneurship Monitor's "2000 Executive Report" between 1997 and 2000 private investors, on average, funded 30 to 40 times more start-ups each year than venture capitalists, both in Europe and in the United States.

However it is widely accepted that venture capital is the crucial financial factor that triggered the development of high-tech firms in the United States and that is why European policy makers have been striving to help channel funds into this means of finance (Bottazzi and Da Rin, 2002). It has been contended that the conditions of emergence of venture capital are inseparable from the American "innovation model", which in turn, relates firmcreation to the commercial exploitation of technological advances (Mowery, 1992). Meanwhile it was noted that Europe has experienced significant difficulties in exploiting commercially scientific innovations, and that the divergence between research and commercial application renders high-tech start-ups a far less attractive investment in Europe than in the United States.

Venture capitalists are prepared to invest in high risk, fast growing firms, in exchange for high rates of return, furthermore they are willing to offer their expertise and managerial skills to the typically inexperienced entrepreneur. The newly set up firms are constantly monitored by venture capitalists, who, as a result, are greatly influential on the way the company is run and are capable of blocking projects they deem scantily profitable.

\footnotetext{
${ }^{2}$ http://www.1000ventures.com/presentations/venture_financing_chain.html by Vadim Kotelnikov
} 
Hellman and Puri (2000 and 2001) have found that some of the advantages for firms financed by venture capitalists are: higher growth rates than their competitors, more qualified human capital, they are highly innovative, and generally they market their products faster than their competitors. All the above may be influenced favourably by the fact that venture capitalists are usually experienced executives or entrepreneurs, often with a technical background, that provide "reputation capital" so that venture-backed firms are more likely to entice top executives or obtain new contracts. Furthermore venture capitalists are prepared to offer not only their knowledge and skills in the field but also and equally importantly their business and marketing expertise and network of connections in order to see their investment grow at the utmost rate possible.

As a matter of fact, an important point to bear in mind is that venture capitalists aim at achieving the highest possible rate of return once the firm is ready to exit the phase of external financing either by going public or by acquisition, by the owner or a larger company. The possibility of going public is especially favoured by venture capitalists who can then be guaranteed a fair price in the capital market. Black and Gilson (1998) illustrate that venture capitalists do play a decisive role in helping firms reach a sufficient size to go public. It is now clear why venture capital financing can only thrive where financial markets are highly developed.

European public authorities have recently intensified support to venture capital as innovative way of financing. Dubocage and Rivaud-Danset (2002) argue that handicaps inherent in the financial systems of some Western European countries are the main reason for them lagging behind the US in the development of a thriving high-tech industry and therefore justify the intervention of public authorities. However there is still a great deal of diffidence on whether the Anglo-Saxon model should be applied as it is in continental Europe, due to structural and institutional differences.

\section{The Role Of Public Equity Markets}

Carpenter and Petersen (2002) argue that the availability of external equity finance may give a nation a comparative advantage in developing its high-tech sector. It is believed that an efficient financial system based on highly accessible equity markets and extensive venture capital has given the US an ever widening lead on Europe on the expansion of its high-tech industry and of a new economy. Furthermore, Gompers and Lerner (1997) found that Initial Public Offerings (IPOs) are by far the most profitable exit from a venture investment, corroborating once again the significance of efficient capital markets for the development of venture capital.

As for venture capital, we posit that several factors helped it to succeed in effectively financing the new economy enterprises in the United States, firstly the presence of a well-developed and homogeneous capital market with a single legal system, secondly an initial intervention by the government, thirdly the flexibility in the labour market and liquidating procedures, fourthly harmonized trading accounting standards across the States. Conversely, Europe has suffered from heterogeneous, insufficiently sizeable and efficient capital markets, which implied high transaction costs and the presence of information asymmetries. We will come back to this point later on.

Bottazzi and Da Rin (2002) analysed a dataset on European venture capital taken from the listing of Euro.nm, the coalition of Europe's "new" stock markets ${ }^{3}$ for companies operating in high-growth industries. They found that nearly $40 \%$ of the companies listed on the Euro.nm were backed by at least one venture capitalist, and that while syndication of venture investment is quite common in the United States (Lerner 1994), it is far less frequent in Europe where over half of the firms included in Bottazzi and Da Rin's sample ${ }^{4}$ were backed by only one venture capitalist.

Finally it was found that most European venture capitalists show greater interest in companies that are at their very first stages of their development which reinforces the idea of venture capital as a precious source of funds. Another significant dissimilarity between the European and American venture capital sector is the composition of

\footnotetext{
${ }^{3}$ Euro.nm was opened in 1997, on the lines of the American index NASDAQ, and comprised the "new stock markets" of Amsterdam, Brussels, Frankfurt, Paris and Milan. Euro.nm closed in 2000 after the French, Dutch and Belgian stock exchanges merged to form Euronext, however its components continued to operate independently.

${ }^{4}$ Bottazzi and Da Rin's dataset included $90 \%$ of the total number of firms listed on Euro.nm
} 
venture capitalists, generally financial institutions in Europe (particularly in Germany and the UK), which are generally somewhat risk averse and therefore prefer to channel their funds into more mature industries.

However the opening of Euro.nm seems to have sparked off a new form of venture capital, more similar to the American one, independent and more attracted to the higher returns attainable with investments in innovative high-tech firms. There is little doubt that a dynamic and efficient stock market renders IPOs easier and more inexpensive for companies and, as a result, venture capital becomes more appealing for investors.

Particularly in France and Germany, the opening of the Euro.nm seems to be highly correlated with a sharp increase in venture capital activity at national level as well as at European level (EVCA 2001). While the benefits of the Euro.nm have been recognised, a Research Paper published in 2004 by the European Private Equity \& Venture Capital Association (European stock market financing for high-growth companies) points at the fragmentation of the European financial markets as the main reason for their failure (Euro.nm was closed in 2000). It has been demonstrated that fragmentation has led to an increase in the transaction costs and a decrease in liquidity of European stock markets which together accounted for an average transaction cost three to seven times higher than in the United States and for estimated total transaction fees three to ten times higher than in the US market (Ferrary, Groslambert and Antipolis, 2004). It was in fact established by Pagano, Roell and Zechner (2001) that the European Stock Exchange where trading costs were the highest had the lowest ability to attract foreign listings. Hence the EVCA suggests the creation of a single trading platform through the merger of all the European stock exchanges to create economies of scale and reduce access costs.

\section{European Financial Systems And The Role Of Public Policies}

Despite being commonly accepted as one of the factors indispensable to the expansion of venture capital, the presence of a market-based financial system, as opposed to a bank-based system, does not seem a sufficient explanation for it. As a matter of fact, if we look at the figures published by the EVCA in 2002, and adapted by Dubocage and Rivaud-Danset (2004), we note that for the years 1999, 2000 and 2001 German high-tech firms funded by venture capital constantly outnumbered British firms in the same sector. The quantitative results obtained by the EVCA might appear somewhat surprising if we follow the theory that well-developed capital markets are essential to a booming venture capital system. It is broadly recognised (Lockett, Murray and Wright, 2002 and La Porta et al. 1997) that the UK market-based system is the closest to the American model in Europe, and, in theory, the most appropriate for venture capital financing of high-growth enterprises. In reality though, for the years 1999 to 2001, the German model, typically bank-based, seems to have been more successful than the UK in channelling venture capital funds into the high-tech sector, perhaps an indication of British venture capitalists' preferences for less risky investments. Germany also surpassed the UK in terms of number of projects funded by venture capital, amounts invested and, except for the year 2000, percentage of GDP invested.

A possible reason for this apparent surprising outcome could be that pension funds are the main providers of UK investments, and typically their fund managers have a preference for low-risk portfolios. Furthermore the relative lack of government policies supporting venture capital and high-tech firms in the 1990s may have had a negative impact on the development of venture capital in the UK. It was indeed the high level of support from the government that greatly helped Germany's venture capitalists to finance the high-tech industry more than in many other European countries, so that banks have become main suppliers of capital to venture capitalists.

In France, where like in Germany the bank-based financial model is predominant, for many years public authorities have proposed and implemented policies to assist high-tech enterprises in order to remain competitive in the global market. The first half of the 1980s saw the creation of venture capital mutual funds and companies, and of the "Second Marché", a capital market for Small and Medium Enterprises (SMEs). However it wasn't until the second half of the 1990s, with the opening of the Nouveau Marché that venture capital took off as a financing solution and the number of venture capital deals went from 942 in 1998 to 2130 in 2000 (EVCA, 2002). The most recent policies adopted by the French government aim at encouraging the best ways of financing small high-tech firms, believed to be a key sector to France's international competitiveness. 
As for Italy, the venture capital industry has been growing in the late 1990s, also thanks to the creation of the Nuovo Mercato in 1999, as a new member of the Euro.nm. However, the poor efficiency of the capital market and the negative attitude of Italian firms to going public (Pagano, Panetta and Zingales, 1998) have hindered the potential of venture capital to fund high-tech start-ups. Furthermore, as noted by Schivardi and Trento (2000), historically the Italian economy has been based on sectors that are not information or technology intensive, such as leather, clothing, shoes and this peculiarity may be at least partially responsible for the delay and sluggishness of the Italian high-tech industry with respect to its European and North American competitors. Public policies in support of venture capital here have been almost non-existent and when they have been put in place they have had mainly a regional impact, with the north of Italy leading the way with the creation of venture capital funds promoted by local agencies ${ }^{5}$.

The European Commission itself historically has had a policy of encouraging venture capital within the Union, as the transformation of the European Investment Fund into a major investor in venture capital funds demonstrates. From a recent report on Public Policy Priorities by the EVCA (2005) it was noted that the fast-growing knowledge-based high-tech sector in Europe is still at an embryonic stage if compared to similar industries in North America or Far East. The EVCA put forward nine recommendations to boost innovation, the development of the hightech sector and venture capital as a main source of funding. The first and second recommendations are concerned with fostering Europe's entrepreneurial environment and culture by "implementing an effective pan-European structure" to boost a harmonized marketplace, "simplifying the requirements for company formation, lightening the burden of regulatory and administrative compliance costs, improving access to finance at all levels" and setting out support programmes for potential entrepreneurs. The third, fourth and fifth recommendations aim at boosting innovation and R\&D programmes mainly by "enlarging the flow of information and technology transfer between universities and the private sector", bestow incentives and benefits to young innovative companies from the early stages of their development, provide a "clear and efficient system for intellectual property rights". Finally the last four recommendations are concerned with the raising and deployment of private equity and venture capital funds as engines for a successful high-growth sector. More in detail the sixth recommendation suggests that the EU Pension Fund Directive should be implemented effectively. This would allow pension funds to allocate more resources to higher-yielding assets in their portfolios; capital adequacy and solvency requirement should duly reflect the real risks and returns involved in private equity and venture capital investments. The seventh and eighth recommendations state that public funds and public efforts in promoting entrepreneurship should be channelled more effectively to specific sectors, stages and areas; also the creation of a pan-European marketplace for private equity and venture capital funds to facilitate cross-border investments is called for. The ninth recommendation avows the creation of an integrated panEuropean trading platform and of a quoted market for high-potential firms to ensure long term liquidity is available.

\section{DATA AND REGRESSIONS}

The proposed causes for growth of technology companies are now tested using an ordinary least squares regression approach. The six independent variables used correspond to major hypothesised causal factors in the technological sector's expansion. The first of these is business enterprise expenditure on research and development as a percentage of GDP (BERD). It measures the financial commitment of business to its own research and development. A second independent variable is the percentage of higher education expenditure on R\&D funded by industry (industry HERD). It quantifies the links between business and higher education. A third independent variable is government expenditure on R\&D as a percentage of GDP (GOVERD), reflecting government involvement in research and development.

Equity stocks traded in the domestic market as a percentage of GDP (stocks traded) is the fourth independent variable and reflects how much an economy is financed by non-bank sources. The fifth independent variable is the total unemployment rate as a percentage of the labour force (unemployment), intended to measure the extent of labour market liberalisation with low unemployment indicating higher liberalisation or at least a greater ability to recover a job if one is lost. This is an imperfect measure, but is convenient and accessible. The number of patents in the ICT

\footnotetext{
${ }^{5}$ Presentation in Tallin in 2002 by Giorgio Monaci, Settore Economia e Lavoro, "Coordination of innovation strategies in metropolitan areas. The role of public policies."

http://64.233.161.104/search?q=cache:0P_RPsa9L8cJ:www.madrimasd.org/informacionIDI/PoliticasRegionales/metropolis/documentos/Tallinn_( Milan).ppt+venture+capital+italy+public+policy\&hl=en
} 
and biotechnology sectors registered at the USA Patent and Trademark Office in 1990 (initial patents) is the sixth and final independent variable, and indicates the initial technological development. The use of a USA office means that the United States' starting high-tech advantage is inflated compared with other countries.

Data is taken from the World Bank World Development Indicators (2004) and the OECD Main Science and Technology Indicators 2004, Edition 2. The data is for OECD countries, together with Argentina, China, Israel, Romania, Russian Federation, Singapore, and Slovenia. Except for the initial patents, all figures are at 1999 or the nearest year with available data. The initial number of patents is included in order to assess how initial technology advantage or a large existing technology sector affects future growth. The expectation would be that a large initial technology sector would slow down growth because it is harder to expand from a very large starting base, although there may be some early mover advantage for precocious countries.

The first dependent variable assessed is the percentage increase in patents from 1990 to 1999 in the ICT and biotechnology sectors, also from the OECD Indicators. The variable is intended to reflect the extent to which innovative commercial projects are generated in the economy, after the opportunities to develop them were presented in the 1990s. Where the number of patents was zero in 1990 and non-zero in 1999, an increase of $1000 \%$ was assumed.

Models were generated and tested sequentially. The regression coefficients are estimated, and the least significant variables are successively removed to generate new models until all remaining variables are significant and the regression remains a good fit, or is the closest achievable to it. Table 1 shows the results.

Table 1: Determinants Of Initial Commercial Technological Innovation Dependent variable is the percentage increase in the number of technology patents from 1990-1999

\begin{tabular}{|c|c|c|c|c|c|c|c|c|}
\hline \multirow{2}{*}{$\begin{array}{l}\text { Independent } \\
\text { variables }\end{array}$} & \multicolumn{2}{|l|}{ Model } & \multicolumn{2}{|l|}{ Model } & \multicolumn{2}{|l|}{ Model } & \multicolumn{2}{|l|}{ Model } \\
\hline & 1 & & 2 & & 3 & & 4 & \\
\hline Constant & $\begin{array}{c}350.70 \\
(563.82)\end{array}$ & 0.54 & $\begin{array}{c}308.75 \\
(496.74)\end{array}$ & 0.54 & $\begin{array}{c}260.89 \\
(471.00)\end{array}$ & 0.58 & $\begin{array}{c}123.83 \\
(322.03)\end{array}$ & 0.70 \\
\hline BERD & $\begin{array}{c}-80.48 \\
(216.30)\end{array}$ & 0.71 & $\begin{array}{c}-73.60 \\
(208.89)\end{array}$ & 0.73 & & & & \\
\hline Industry HERD & $\begin{array}{c}-3.52 \\
(21.06)\end{array}$ & 0.87 & & & & & & \\
\hline GOVERD & $\begin{array}{c}839.40 \\
(1,092.65)\end{array}$ & 0.45 & $\begin{array}{c}851.18 \\
(1,072.57)\end{array}$ & 0.43 & $\begin{array}{c}781.71 \\
(1,039.29)\end{array}$ & 0.46 & $\begin{array}{c}859.17 \\
(1,007.96)\end{array}$ & 0.40 \\
\hline Stock trades & $\begin{array}{c}1.66 \\
(2.61)\end{array}$ & 0.53 & $\begin{array}{c}1.66 \\
(2.57)\end{array}$ & 0.52 & $\begin{array}{c}1.38 \\
(2.40)\end{array}$ & 0.57 & $\begin{array}{c}1.50 \\
(2.35)\end{array}$ & 0.53 \\
\hline Unemployment & $\begin{array}{l}-16.60 \\
(37.49)\end{array}$ & 0.66 & $\begin{array}{l}-15.84 \\
(36.61)\end{array}$ & 0.67 & $\begin{array}{l}-14.48 \\
(35.89)\end{array}$ & 0.69 & & \\
\hline Initial patents & $\begin{array}{l}-0.04 \\
(0.05)\end{array}$ & 0.47 & $\begin{array}{l}-0.04 \\
(0.05)\end{array}$ & 0.46 & $\begin{array}{l}-0.04 \\
(0.05)\end{array}$ & 0.39 & $\begin{array}{l}-0.04 \\
(0.04)\end{array}$ & 0.41 \\
\hline $\mathrm{N}$ & 36 & & 36 & & 36 & & 36 & \\
\hline $\mathrm{R}^{2}$ & 0.05 & & 0.05 & & 0.05 & & 0.04 & \\
\hline
\end{tabular}

Standard errors are shown below the coefficients; p-values are shown to the right. 
Under model 1, industry funding of higher education is smaller than the other factors in its effect on the percentage increase in technology patents. It is small in its absolute effect except on the outliers China (when it reduces the increase in the number of technology patents by 114\%) and to a lesser extent Russia, Romania, and Turkey. The largest mean average contribution comes from government research and development, increasing patent growth by $204 \%$.

The unemployment rate has the next highest absolute effect on average, decreasing patent growth by $124 \%$. It has a very low level of significance, however. The signs of both BERD and industry HERD were negative, but highly insignificant, indicating a lack of responsiveness of patent issue growth to business research and development, either directly or through university funding. On the other hand, an increase in stocks traded tends to increase the rate of patent innovation.

After removing industrial HERD, BERD, and unemployment, the lowest p-value on the remaining three nonconstant coefficients is 0.4 and the $\mathrm{R}^{2}$ is 0.04 , indicating that the data shows little evidence of their impact on patent issues, at least at the aggregate level. The conclusions from the analysis are subject to considerable uncertainty because of the low level of significance in the parameters and low regression $\mathrm{R}^{2}$.

For countries with a very small number of patents, the number of possible causes of an increase in patents is large - the shift in a political system among the Eastern European countries, a slight change in regulatory regime, or even the presence of a single entrepreneur. The result is a large variability for these countries and a low $\mathrm{R}^{2}$. The starting regression has very low explanatory power, which does not decline to a great extent as the low significance variables are excluded. To remove the effect of such varied factors, only countries with starting patent numbers greater than ten are considered in Table 2.

Table 2: Determinants Of Initial Commercial Technological Innovation, For Countries With Initial Patents Greater Than Ten

\begin{tabular}{|c|c|c|c|c|c|c|c|c|c|c|}
\hline $\begin{array}{l}\text { Independent } \\
\text { variables }\end{array}$ & $\begin{array}{c}\text { Model } \\
5\end{array}$ & & $\begin{array}{c}\text { Model } \\
6\end{array}$ & \multicolumn{2}{|r|}{$\begin{array}{c}\text { Model } \\
7 \\
\end{array}$} & \multicolumn{2}{|r|}{$\begin{array}{c}\text { Model } \\
8 \\
\end{array}$} & \multicolumn{3}{|c|}{$\begin{array}{c}\text { Model } \\
9\end{array}$} \\
\hline Constant & $\begin{array}{c}-50.97 \\
(111.52)\end{array}$ & 0.65 & $\begin{array}{l}-45.18 \\
(97.30)\end{array}$ & 0.65 & $\begin{array}{l}-35.06 \\
(90.65)\end{array}$ & 0.70 & $\begin{array}{c}1.96 \\
(69.97)\end{array}$ & 0.98 & $\begin{array}{c}8.67 \\
(70.40)\end{array}$ & 0.90 \\
\hline BERD & $\begin{array}{c}71.76 \\
(41.85)\end{array}$ & 0.11 & $\begin{array}{c}72.13 \\
(40.43)\end{array}$ & 0.09 & $\begin{array}{c}73.97 \\
(39.06)\end{array}$ & 0.08 & $\begin{array}{c}71.85 \\
(38.31)\end{array}$ & 0.08 & $\begin{array}{c}58.86 \\
(37.01)\end{array}$ & 0.13 \\
\hline Industry HERD & $\begin{array}{c}8.07 \\
(3.75)\end{array}$ & 0.05 & $\begin{array}{c}8.14 \\
(3.59)\end{array}$ & 0.04 & $\begin{array}{c}8.07 \\
(3.49)\end{array}$ & 0.03 & $\begin{array}{c}8.03 \\
(3.43)\end{array}$ & 0.03 & $\begin{array}{c}8.11 \\
(3.46)\end{array}$ & 0.03 \\
\hline GOVERD & $\begin{array}{c}29.03 \\
(243.00)\end{array}$ & 0.91 & & & & & & & & \\
\hline Stock trades & $\begin{array}{c}0.16 \\
(0.44)\end{array}$ & 0.72 & $\begin{array}{c}0.15 \\
(0.42)\end{array}$ & 0.73 & & & & & & \\
\hline Unemployment & $\begin{array}{c}4.72 \\
(7.37)\end{array}$ & 0.53 & $\begin{array}{c}4.81 \\
(7.10)\end{array}$ & 0.51 & $\begin{array}{c}4.53 \\
(6.87)\end{array}$ & 0.52 & & & & \\
\hline Initial patents & $\begin{array}{l}-0.01 \\
(0.01)\end{array}$ & 0.34 & $\begin{array}{l}-0.01 \\
(0.01)\end{array}$ & 0.33 & $\begin{array}{l}-0.01 \\
(0.01)\end{array}$ & 0.34 & $\begin{array}{l}-0.01 \\
(0.01)\end{array}$ & 0.26 & & \\
\hline $\mathrm{N}$ & 22 & & 22 & & 22 & & 22 & & 22 & \\
\hline $\mathrm{R}^{2}$ & 0.32 & & 0.32 & & 0.31 & & 0.29 & & 0.24 & \\
\hline
\end{tabular}

Standard errors are shown below the coefficients, p-values are shown to the right. 
The signs of the coefficients in model 5 are as expected. Business expenditure on research and development, whether internal or through university funding, increases patent registration as well as government expenditure on research and development, the volume of stock market trading, and the rate of unemployment, although they are at statistically insignificant even at the 50\% level. After removing these least significant variables successively, regression 8 shows that the number of initial patents just fails to reach the $25 \%$ level of significance. It does have the expected sign with late technological developers able to catch up more quickly on early developers. Its mean average effect is six times less than the effect of industry HERD, or almost ten times less than BERD.

Excluding the initial number of patents from the final regression confirms the significance at a $5 \%$ level for industry HERD and at the $15 \%$ level for BERD. On balance, it is not surprising that the key determinants of commercial innovation should be business-financed funding. It is a little more surprising that government research and development expenditure seems to have so little effect on the initial development of commercialised products. It is possible that government research and development is generic or public-service based, rather than commercially oriented. There is equally no indication, through a statistically significant negative coefficient, that the government is crowding-out private sector innovation. The regressions have a moderate degree of explanatory power, at $\mathrm{R}^{2}=0.32$ for regression 5, falling to $\mathrm{R}^{2}=0.24$ for regression 9 .

The dependent variable in the regressions changes in Table 3, to the ICT contribution to economic growth from 1991 to 1997. The idea is to find determinants of the effect of ICT on economic growth. The previous regressions examine the initial stages of producing a commercial product; the next set of regressions includes this stage, and also the conversion of the patented idea into a lucrative market. It would consequently be expected that a wider or different set of independent variables would be important here than in the previous regressions. The data for ICT contribution to growth was a sixteen country sample from Daveri (2000), comprising of Germany, France, United Kingdom, Italy, Spain, Netherlands, Belgium, Denmark, Sweden, Finland, Norway, Japan, Australia, New Zealand, Canada, and United States.

Table 3: Determinants Of The Effect Of ICT On Economic Growth

Dependent variable is ICT contribution to GDP

\begin{tabular}{|c|c|c|c|c|c|c|c|c|c|c|}
\hline $\begin{array}{l}\text { Independent } \\
\text { variables }\end{array}$ & $\begin{array}{c}\text { Model } \\
10\end{array}$ & & $\begin{array}{c}\text { Model } \\
11\end{array}$ & & $\begin{array}{c}\text { Model } \\
12\end{array}$ & & $\begin{array}{c}\text { Model } \\
13\end{array}$ & & $\begin{array}{c}\text { Model } \\
14\end{array}$ & \\
\hline Constant & $\begin{array}{c}0.42 \\
(0.16)\end{array}$ & 0.03 & $\begin{array}{c}0.42 \\
(0.15)\end{array}$ & 0.02 & $\begin{array}{c}0.37 \\
(0.13)\end{array}$ & 0.02 & $\begin{array}{c}0.52 \\
(0.08)\end{array}$ & 0.00 & $\begin{array}{c}0.58 \\
(0.07)\end{array}$ & 0.00 \\
\hline BERD & $\begin{array}{l}-0.02 \\
(0.04)\end{array}$ & 0.59 & $\begin{array}{l}-0.03 \\
(0.04)\end{array}$ & 0.53 & & & & & & \\
\hline Industry HERD & $\begin{array}{c}0.01 \\
(0.01)\end{array}$ & 0.18 & $\begin{array}{c}0.02 \\
(0.01)\end{array}$ & 0.15 & $\begin{array}{c}0.02 \\
(0.01)\end{array}$ & 0.12 & $\begin{array}{c}0.01 \\
(0.01)\end{array}$ & 0.22 & & \\
\hline GOVERD & $\begin{array}{c}0.38 \\
(0.31)\end{array}$ & 0.25 & $\begin{array}{c}0.38 \\
(0.29)\end{array}$ & 0.23 & $\begin{array}{c}0.40 \\
(0.28)\end{array}$ & 0.19 & & & & \\
\hline Stock trades & $\begin{array}{l}0.001 \\
(0.00)\end{array}$ & 0.09 & $\begin{array}{l}0.001 \\
(0.00)\end{array}$ & 0.06 & $\begin{array}{l}0.001 \\
(0.00)\end{array}$ & 0.06 & $\begin{array}{l}0.001 \\
(0.00)\end{array}$ & 0.12 & $\begin{array}{l}0.001 \\
(0.00)\end{array}$ & 0.12 \\
\hline Unemployment & $\begin{array}{l}-0.03 \\
(0.01)\end{array}$ & 0.01 & $\begin{array}{l}-0.03 \\
(0.01)\end{array}$ & 0.01 & $\begin{array}{l}-0.02 \\
(0.01)\end{array}$ & 0.01 & $\begin{array}{l}-0.03 \\
(0.01)\end{array}$ & 0.01 & $\begin{array}{l}-0.02 \\
(0.01)\end{array}$ & 0.01 \\
\hline Initial patents & $\begin{array}{c}0.00 \\
(0.00)\end{array}$ & 0.86 & & & & & & & & \\
\hline $\mathrm{N}$ & 16 & & 16 & & 16 & & 16 & & 16 & \\
\hline $\mathrm{R}^{2}$ & 0.64 & & 0.64 & & 0.62 & & 0.56 & & 0.49 & \\
\hline
\end{tabular}

Standard errors are shown below the coefficients; p-values are shown to the right. The initial independent variables are the same as in the previous tables. 
The initial specification in model 10 proves to be a good fit to the available data with an $\mathrm{R}^{2}$ of 0.64 . Even after the less significant variables are successively removed, the model stays a good fit, with model 14 having just two independent variables and an $R^{2}$ of 0.49 . The two retained variables in model 14 are unemployment, which is significant at the $1 \%$ level, and the size of the stock market, which is significant at the $15 \%$ level. They are the two variables identified with the ability of entrepreneurs to realise profitable investments through Initial Public Offerings, or to terminate unprofitable ones, thereby dismissing the workforce. The signs of the coefficients support the thesis that it is a market-driven economy and liberal labour laws which encourage the realisation of investments in technology start-up companies.

In model 10, the coefficient for the level of initial patents has a very low level of significance. Initial patents have less effect on contribution to GDP growth than on the initial development of commercial products, as measured by increases in the number of patents. An explanation is that earlier technological innovation would have less effect on the profits following from technology investments than on innovation itself, as there are fewer direct links between past innovation and future commercialisation than past and future innovation.

The source and direction of research and development funding show a moderate effect on ICT's macroeconomic contribution. The coefficient of business research and development in Regression 10 is not significantly different from 0 even at the $50 \%$ level, while the p-values of government research and industrially funded university research are 0.19 and 0.12 in model 12 , after removing the two least significant variables. The overall model 12 regression $\mathrm{R}^{2}$ is 0.62 , while the non-reported adjusted $\mathrm{R}^{2}$ is 0.49 . Balancing goodness of fit and informative model specification, this model is appealing. The mean average contribution of government and industrially funded university research actually exceeds that of stocks traded $(0.09 \%, 0.1 \%$, and $0.07 \%$, respectively). As anticipated, the growth of the technology sector depends on both establishing the initial research funding for it, and then providing an adequate financial framework for entrepreneurs to exploit it commercially.

\section{CONCLUSIONS}

Undoubtedly, innovative ICT firms have been playing an essential role in the economic revolution that places the United States in leading position on the world's economic stage. The emphasis has been on the role played by the American-style, liberal, market-based financial system which has been advocated as one of the master keys to the rapid growth of the high-tech industry. By contrast, with regard to the sluggish development of the technological sector as driving industry in the European economy, many authors believe that as stated by Bugamelli et al. (2003), "without a radical innovation in the financial sector, the emergence of the new economy would be dwarfed in that the productive system would not take full advantage of the wave of technological innovation".

With the present study we used a regression analysis to determine how crucial an effective financial system is to a healthy and swift expansion of the high-tech sector, but also to measure the importance of structural factors such as business expenditure on research and development, higher education expenditure on R\&D funded by industry, government expenditure on $\mathrm{R} \& \mathrm{D}$, the extent of labour market liberalisation and the initial level of technological development. This paper differentiates and analyses the financial and structural factors influencing the development of innovation and those influencing its conversion to economic growth.

We examined two stages of the development: the initial stage is represented by the extent to which innovative commercial projects are generated in the economy, while in the second stage of our data analysis we want to discover the determinants of the effect of ICT on economic growth. Hence, the first set of regressions investigates the initial phases of creating an innovative product or service; while the second set of regressions also includes the conversion of the patented idea into a lucrative market that is the commercial exploitation of technological advances. As for the first stage of the analysis we find that, not surprisingly, business funding in the form of firm expenditure on research and development and industry funding of higher education expenditure on R\&D are key determinants of commercial innovation. Conversely, our results show, unexpectedly, that government funding of research and development has a rather modest impact on the initial development of marketable high-tech products. One possible explanation is that government $R \& D$ expenditure is more public-service oriented rather than commercially oriented. 
The regressions for the second part of our analysis have a much higher degree of explanatory power than for the first phase. Unemployment and the size of the stock market are the two independent variables, amongst those considered, that seem to have a predominant effect on the conversion of innovation into profit-making inventions. The above outcome appears to reinforce the idea that labour market flexibility and a financial system based on an efficient equity market are especially significant factors for a thriving high-tech industry. This is due primarily to the importance attributed by investors to the prospect of achieving high returns on their investments through Initial Public Offerings, or to be able to terminate unprofitable investments with the assistance of liberal labour laws. Furthermore, we found that the initial number of patents has a reduced effect on the contribution to GDP growth than on the early development of commercial products. An explanation could be that early technological innovation may have a less significant effect on profits from technology investments if innovation itself is not exploited commercially. This is in fact considered one of the main dissimilarities between the European and the American "innovation model" that relates firm-creation to the commercial exploitation of technological advances (Mowery, 1992).

Our findings also show that the effect of the average contribution of governments and the industrial funding of university research to the growth of the "new economy" exceeds that of stocks traded $(0.09 \%, 0.1 \%$, and $0.07 \%$, respectively). Hence, it can be concluded that the growth of high-tech industries depends heavily on an appropriate and satisfactory initial R\&D funding to start-ups and research centres and on adequate financial and legal frameworks for entrepreneurs and investors. The development of a profitable and sustainable technology industry appears to be fragmented across different European countries, with Germany, the UK and the Scandinavian countries leading the way, despite their very different market structures, while the South of Europe seems to be lagging behind. Particularly in the case of Italy, it seems that there has been very little intervention from the central Government in support of such industry.

The implications for policy-makers at national level are that, to promote a rapid growth of small innovative firms and boost their importance within the national economies, the need for local governments' support to start-ups and universities' research centres is imperative, regardless of the type of financial system adopted. At European level, we do believe that the harmonisation of financial regulations and the creation of a single market with easy access and low transaction costs would prompt many European investors to be more involved with high-tech start-ups. Ease of access, low transaction costs achieved thorough a unique trading platform, and the proximity of the market would allow investors to accomplish their Initial Public Offerings in the continent rather than choosing the American equity market as is currently the case for many Scandinavian companies.

\section{REFERENCES}

1. Akerlof G. A. (2001) Behavioral Macroeconomics and Macroeconomic Behavior Nobel Prize Lecture, December 82001

2. Autio E., W. D. Bygrave, S. M. Camp, M. Hay, and P. D. Reynolds (2000) 2000 Executive Report, Global Entrepreneurship Monitor (GEM)

3. Beck T. and R. Levine (2002) Industry Growth and Capital Allocation: Does Having a Market or Bank based System Matter? Journal of Financial Economics, 64, pp. 147-180

4. Black B. S. and R. J. Gilson (1998) Venture Capital and The Structure of Capital Markets: Banks versus Stock Markets Journal of Financial Economics, 47, 243-277

5. Bottazzi L. and M. Da Rin (2002) Venture Capital in Europe and the Financing of Innovative Companies Economic Policy, 34(1), 229-269

6. Bugamelli M., P. Pagano, F. Paternò, A. F. Pozzolo, S. Rossie, and F. Schivardi (2003) Ingredients for the New Economy: How Much does Finance Matter? Bank of Italy paper

7. BVCA (2002) BVCA Report on Investment Activity 2002 (http://www.bvca.co.uk)

8. Carpenter R. E. and B. C. Petersen (2002) Capital Market Imperfections, High-Tech Investment and New Equity Financing Economic Journal, Royal Economic Society, 112(127), pp. F54-F72

9. Daveri, F. (2000) Is growth an information technology story in Europe too? University of Parma and IGIER paper

10. Dubocage E. and D. Rivaud-Danset (2002) Government Policy on Venture Capital Support in France, Venture Capital, 4(1), 25-43 
11. Dubocage E. and D. Rivaud-Danset (2004) The Development of Venture Capital in Europe, the Role of Public Policy, Capital Market Development and the Economy, Tokyo Club Papers, 16, 76-117

12. EVCA (2001) 2000 Investment Benchmarks Report (http://www.evca.com)

13. ----- (2002) EVCA Corporate Venturing European Activity Update 2001, (http://www.evca.com)

14. - ----- (2005) Report on Public Policy Priorities, (http://www.evca.com)

15. Ferrary G. and B. Groslambert (2004) European Stock Market Financing for High-Growth Companies Research Paper, EVCA (http://www.evca.com)

16. Gompers P. and J. Lerner (1997) Risk and Reward in Private Equity Investments: The Challenge of Performance Assessment Journal of Private Equity, 1(2), 5-12

17. Lerner J. (1994) The syndication of venture capital investments Financial Management, 23(3), 16-27

18. Green R. (2003), The Economic Impact of Private Equity and Venture Capital on the UK Economy (source: http://www.bvca.co.uk)

19. Hellman T. and M. Puri (2000) The Interaction Between Product Market and Financing Strategy: The Role of Venture Capital Review of Financial Studies, 13(4) 959-984

20. Hellman T. and M. Puri (2001) Venture Capital and the Professionalization of Start-up Firms: Empirical Evidence Journal of Finance, 57, pp. 169-197

21. La Porta R., F. Lopez De Silanes, A. Schleifer, and R. Vishny (1997) Legal Determinants of External Finance Journal of Finance, 52, 1131-50

22. Lockett A., G. Murray, and M. Wright, (2002) Do UK Venture Capitalists still have a Bias against Investment in New Technology Firms? Research Policy, 31(6), 1009-30

23. Mowery D.C. (1992) The US National Innovation System: Origins and Prospects for Change Research Policy 21, 125-144

24. Pagano M, A. A. Roell, and J. Zechner (2001) The Geography of Equity Listing: Why do Companies List Abroad? CEPR Discussion Papers no 2681, Jan, London.

25. Pagano M., F. Panetta and L. Zingales, (1998) Why Do Companies Go Public? An Empirical Analysis Journal of Finance, 53, 27-64

26. Robinson J. (1952) The Generalization of the General Theory, in The Rate of Interest, and Other Essays, London: Macmillan, pp. 67-142

27. Schivardi F. and S. Trento (2000) La Nuova Economia come una "General Purpose Technology": Implicazioni di Politica Economica Luigi Prosperetti (eds) Papers and proceeding of the 41st annual meeting of the Italian Economic Association.

28. Spence A. M. (2001) Signaling in Retrospect and the Informational Structure of Markets, Nobel Prize Lecture, December 82001

29. Stiglitz J. E. (2001) Information and the Change in the Paradigm of Economics, Nobel Prize Lecture, December 82001 